\title{
Endocrine complications in long-term survivors of childhood cancers
}

\author{
Wassim Chemaitilly and Charles A Sklar ${ }^{1}$
}

Division of Endocrinology, Department of Pediatrics, Children's Hospital of Pittsburgh of UPMC, One Children's Hospital Drive, 4401 Penn Avenue, Pittsburgh, Pennsylvania 15224, USA

${ }^{1}$ Department of Pediatrics, Memorial Sloan-Kettering Cancer Center, 1275 York Avenue, New York, New York 10065, USA

(Correspondence should be addressed to W Chemaitilly; Email: wassim.chemaitilly@chp.edu)

\begin{abstract}
Endocrine disturbances are among the most frequently reported complications in childhood cancer survivors, affecting between 20 and $50 \%$ of individuals who survive into adulthood. Most endocrine complications are the result of prior cancer treatments, especially radiotherapy. The objective of the present review is to discuss the main endocrine complications observed in this population, including disorders of the hypothalamic-pituitary axis, disorders of pubertal development, thyroid dysfunction, gonadal dysfunction, decreased bone mineral density, obesity, and alterations in glucose metabolism with a special focus on recent findings reported from the Childhood Cancer Survivor Study.
\end{abstract}

Endocrine-Related Cancer (2010) 17 R141-R159

\section{Introduction}

Major advances in the care of children diagnosed with cancer have resulted in a significant increase in survival rates over the past 30 years. The improvement in survival rates is attributed to the use of cancer treatments combining surgery, multiagent chemotherapy, and radiotherapy, in addition to remarkable advances in supportive care. Currently, the 5-year survival rate for acute lymphoblastic leukemia (ALL), the most common cancer in childhood, exceeds $80 \%$, while that for Hodgkin's lymphoma, the most common cancer in adolescence, is generally $>90 \%$ (Mariotto et al. 2009).

Approximately $70 \%$ of pediatric cancer survivors will develop at least one medical complication or disability by 30 years from diagnosis, most of which can be attributed to their previous cancer treatments (Oeffinger et al. 2006). Over the past decade, there has been a greater awareness of the frequency and spectrum of these complications. This is in large part due to the efforts of the Childhood Cancer Survivor Study (CCSS) cohort, a retrospective cohort exceeding 14000 individuals treated for cancer during childhood or adolescence at 26 collaborating institutions in the USA and Canada (Diller et al. 2009, Robison et al. 2009). The CCSS continues to generate data on longterm outcomes of survivors of pediatric cancer.
Endocrine disturbances are among the most frequently reported complications in childhood cancer survivors, affecting between 20 and $50 \%$ of individuals, and they frequently occur as late effects of cancer treatments (Diller et al. 2009). Individuals exposed to radiotherapy and high doses of alkylating agents (Table 1; e.g. hematopoietic stem cell transplant (HSCT) recipients, survivors of central nervous system (CNS) tumors, and Hodgkin's lymphoma) are at particularly high risk of developing endocrine complications (Gurney et al. 2003a, Hows et al. 2006). Such treatments can cause direct damage to key endocrine organs such as the hypothalamic-pituitary axis, the thyroid gland, and the gonads; they can also affect bone mass and alter body composition and glucose homeostasis (Table 2). The following review aims at discussing the most common endocrine problems observed in childhood cancer survivors.

\section{Disorders of the hypothalamic- pituitary axis}

Childhood cancer survivors are at risk of multiple hormone deficiencies, often presenting as late effects of a therapy-related injury to the hypothalamus and/or the pituitary (Table 3). 
Table 1 Chemotherapeutic agents associated with germ cell damage

\begin{tabular}{l}
\hline Alkylating agents \\
Cyclophosphamide \\
Ifosfamide \\
Procarbazine \\
Busulfan \\
Melphalan \\
Thiotepa \\
Nitrosoureas \\
BCNU (carmustine) \\
CCNU (lomustine) \\
Cisplatin
\end{tabular}

\section{GH deficiency}

Impaired linear growth resulting in adult short stature occurs frequently in childhood cancer survivors, particularly in individuals treated at a young age. Both endocrine and non-endocrine factors can contribute to growth retardation. Endocrine factors include GH deficiency (GHD), central precocious puberty (CPP), and primary hypothyroidism. The impact of non-endocrine factors falls beyond the scope of this review, and is mainly represented by the direct damage to the growth plate, mainly of the vertebrae, by highdose radiotherapy, as following total body irradiation (TBI). The result is a skeletal dysplasia where the sitting height is more affected than the standing height (Shalet et al. 1987, Clayton \& Shalet 1991a,b, Brauner et al. 1993, Thomas et al. 1993). A direct and lasting impact of high-dose chemotherapy on the growth plate has not been clearly established (Gleeson et al. 2003, Gurney et al. 2003b).

GHD can occur in childhood cancer survivors as the result of a direct insult to the pituitary gland by tumoral expansion or ablative surgery; tumors, such as craniopharyngiomas, germinomas, and optic nerve gliomas, which arise near the region of the hypothalamus and pituitary, produce GHD as a direct result of the tumor or of the surgery required to remove it. More commonly, however, GHD occurs following irradiation of the hypothalamic-pituitary region.

GHD is the most common and frequently the only anterior pituitary deficit to develop after cranial irradiation (Sklar \& Constine 1995, Laughton et al. 2008). In a study on children treated for embryonal brain tumors, where therapy involved very high doses of radiation to the hypothalamic-pituitary area (median $44 \mathrm{~Gy}$ ), the cumulative incidence of GHD was $93 \%$ at 4 years (Laughton et al. 2008). The site of the damage caused by irradiation is more frequently the hypothalamus, which is more sensitive to irradiation than the pituitary, and can be affected by low doses of irradiation (i.e. $18 \mathrm{~Gy}$ of conventional fractionated radiotherapy; Costin 1988, Oglivy-Stuart et al. 1994). The pituitary gland itself appears to be damaged only at higher doses of irradiation (Costin 1988).

GHD following the irradiation of the hypothalamicpituitary region occurs in a time- and dose-dependent fashion, i.e. the higher the dose of radiation and the longer the interval from treatment, the greater the risk (Clayton \& Shalet 1991a,b). Thus, GHD can be observed within 5 years of external beam radiation when the doses exceed 30 Gy (Laughton et al. 2008). However, following lower doses, such as 18-24 Gy, GHD may not become evident for 10 or more years (Brennan et al. 1998). The use of TBI in children treated with HSCT has been associated with GHD, which may occur years after the completion of all treatment modalities (Sklar 1997). Radiation-induced GHD is usually permanent; some authors nevertheless recommend retesting patients for GHD after the completion of linear growth before considering treatment with GH through adulthood (Holm et al. 1996, Couto-Silva et al. 2000, Growth Hormone Research Society 2000, Gleeson et al. 2004).

The effects of chemotherapy on the GH-insulin-like growth factor 1 (IGF1) axis are not as well established as those of radiotherapy. Growth failure and abnormal GH stimulation test results have been reported in a small number of patients treated with the combination of cyclophosphamide and busulfan prior to HSCT (Bakker et al. 2004). In one study involving 800 survivors treated with chemotherapy alone, linear growth deceleration was noted in 31 individuals, 15 of whom were diagnosed with GHD (Rose et al. 2004).

In the absence of a 'gold standard' diagnostic test for GHD, establishing the diagnosis can be difficult in childhood cancer survivors. The diagnosis is based on the convergence of clinical features and laboratory results. GHD should be suspected in patients with a decreased growth velocity observed over a 6-month time interval (Reiter \& Rosenfeld 2003). Measurement of the sitting height in patients who received irradiation to the spine is helpful for the diagnosis and monitoring of radiation-induced skeletal dysplasia (Clayton \& Shalet 1991a,b). Pubertal staging is important as concurrent precocious puberty can mask the clinical signs of GHD with seemingly normal growth rates owing to the inappropriate secretion of sex steroids. Body weight and body mass index (BMI) are important markers of nutritional status that can influence linear growth.

$\mathrm{GH}$ stimulation tests rely on the measurement of the maximum value of $\mathrm{GH}$ over a $2 \mathrm{~h}$ time period 
Table 2 Endocrine complications and therapy-related risk factors

\begin{tabular}{|c|c|c|}
\hline System & Complication & Therapy-related risks \\
\hline \multirow[t]{3}{*}{ Linear growth } & Skeletal dysplasia & $\begin{array}{l}\text { Radiotherapy to the spine. Younger the age and } \\
\text { higher the dose, greater the risk }\end{array}$ \\
\hline & GH deficiency & Surgery \\
\hline & & Cranial radiotherapy \\
\hline \multirow[t]{2}{*}{ Puberty } & Precocious puberty & Cranial radiotherapy \\
\hline & Hypogonadotropic hypogonadism & Cranial radiotherapy \\
\hline \multirow[t]{4}{*}{ Testes } & Leydig cell dysfunction & Alkylating agents \\
\hline & & Radiotherapy to the testes \\
\hline & Germ cell dysfunction & Alkylating agents \\
\hline & & Radiotherapy to the testes \\
\hline \multirow[t]{4}{*}{ Ovaries } & Acute ovarian failure & Alkylating agents \\
\hline & & Radiotherapy to the ovaries \\
\hline & Premature menopause & Alkylating agents \\
\hline & & Radiotherapy to the ovaries \\
\hline \multirow[t]{3}{*}{ Adrenals } & ACTH deficiency & Direct insult (surgery, tumoral expansion) \\
\hline & & Cranial radiotherapy \\
\hline & & Glucocorticoids (transient) \\
\hline \multirow[t]{7}{*}{ Thyroid } & TSH deficiency & Cranial radiotherapy \\
\hline & Primary hypothyroidism & Radiotherapy (local or scatter) \\
\hline & & $\begin{array}{l}\text { TBI } \\
{ }^{131} \text { I-MIBG and }{ }^{131} \text { I-labeled monoclonal antibody }\end{array}$ \\
\hline & & Cranial radiotherapy \\
\hline & Primary hyperthyroidism & Radiotherapy (local or scatter) \\
\hline & Autoimmune disease & HSCT \\
\hline & Neoplasms & Radiotherapy (local or scatter) \\
\hline \multirow[t]{2}{*}{ Bone } & Osteoporosis & Methotrexate \\
\hline & & Glucocorticoids \\
\hline \multirow[t]{5}{*}{ Metabolism } & Obesity & Cranial radiotherapy \\
\hline & & Glucocorticoids \\
\hline & & Surgery \\
\hline & Diabetes mellitus & Alkylating agents \\
\hline & & TBI and abdominal irradiation \\
\hline
\end{tabular}

${ }^{131}$ I-MIBG, iodine-131-metaiodobenzylguanidine; HSCT, hematopoietic stem cell transplantation.

following the administration of a pharmacologic agent known to increase $\mathrm{GH}$ secretion (or secretagogue). Although widely used, GH stimulation tests are nonphysiologic and often yield non-reproducible results. Failing two stimulation tests using two different secretagogues is generally required for the diagnosis of GHD. Stimulation tests incorporating the insulin tolerance test are believed to be the most reliable, while stimulation tests using arginine combined with GHRH lack sensitivity in individuals treated with radiotherapy (Lissett et al. 2001, Darzy et al. 2003, Björk et al. 2005). Failing one stimulation test was considered enough in patients who received irradiation to the hypothalamus and/or pituitary in the consensus guidelines published by the Growth Hormone Research Society (2000). In GH frequent sampling studies, spontaneous GH secretion is assessed by obtaining multiple blood samples every $20 \mathrm{~min}$ over a $12-24 \mathrm{~h}$ period. More frequently, the samples are drawn only at night, during sleep (overnight sampling). Frequent sampling appears to be more reliable than $\mathrm{GH}$ stimulation tests, but is labor intensive and is available only in a few academic centers (Chemaitilly et al. 2003). IGF1 and IGF-binding protein 3 (IGFBP3) are routinely used as surrogate markers of GH secretion in children assessed for short stature. However, IGF1 and IGFBP3 levels are not reliable indicators of the GH status following cranial irradiation or in cases of a CNS lesion as patients with documented hypothalamic/ pituitary injury due to irradiation or tumoral expansion as the levels of this growth factors can be in the normal range, despite the presence of GHD (Sklar et al. 1993, Weinzimer et al. 1999).

Contemporary GH replacement regimens have been shown to improve final height prospects in childhood cancer survivors with GHD (Adan et al. 2000, Gleeson et al. 2003). Younger bone age at the beginning of $\mathrm{GH}$ replacement and higher doses of $\mathrm{GH}$ positively 
Table 3 Therapy-related complications affecting the hypothalamus/pituitary

\begin{tabular}{|c|c|c|}
\hline Complication & Therapy-related risks & $\begin{array}{l}\text { Relationship to time, dose to the pituitary/ } \\
\text { hypothalamus when applicable, and } \\
\text { available cumulative incidence data }\end{array}$ \\
\hline \multirow[t]{3}{*}{ GH deficiency } & Surgery & Immediate effect \\
\hline & \multirow[t]{2}{*}{ Radiotherapy to hypothalamic-pituitary region } & $\begin{array}{l}\text { Doses }>30 \text { Gy: effect by } 5 \text { years following } \\
\text { exposure. Cumulative incidence } \sim 90 \% \text { over } \\
4 \text { years }\end{array}$ \\
\hline & & $\begin{array}{l}\text { Doses } 18-24 \text { Gy: effect may not become } \\
\text { evident for }>10 \text { years following the exposure }\end{array}$ \\
\hline Precocious puberty & Radiotherapy to hypothalamic-pituitary region & $\begin{array}{l}\text { Doses } 18 \mathrm{~Gy} \text { and above } \\
\text { Increased risk for girls }<5 \text { years with incidence } \\
\text { of } 10-20 \%\end{array}$ \\
\hline $\begin{array}{l}\text { Hypogonadotropic } \\
\text { hypogonadism }\end{array}$ & Radiotherapy to hypothalamic-pituitary region & $\begin{array}{l}\text { Doses }>30 \text { Gy } \\
\text { Incidence } 10-20 \% \text { doses }>50 \text { Gy }\end{array}$ \\
\hline \multirow[t]{3}{*}{ ACTH deficiency } & Surgery & Immediate effect \\
\hline & Radiotherapy to hypothalamic-pituitary region & $\begin{array}{l}\text { Doses > } 30 \text { Gy: possible cumulative incidence } \\
38 \% \text { over } 4 \text { years }\end{array}$ \\
\hline & Glucocorticoids & Effect dose and duration dependent \\
\hline \multirow[t]{2}{*}{ TSH deficiency } & \multirow[t]{2}{*}{ Radiotherapy to hypothalamic-pituitary region } & Doses > 30 Gy \\
\hline & & $\begin{array}{l}\text { Cumulative incidence } 23 \% \text { over } 4 \text { years for } \\
\text { patients treated with doses }>42 \text { Gy }\end{array}$ \\
\hline
\end{tabular}

correlated with a better final height outcome in a report from the CCSS, supported by final height data on 183 childhood cancer survivors treated with GH (Brownstein et al. 2004). In contrast, children previously treated with radiation doses $>20 \mathrm{~Gy}$ to the spine respond less well to GH. For the subset of patients with both GHD and precocious puberty, the combination of $\mathrm{GH}$ and a GnRH agonist that temporarily suppresses puberty appears to improve final height outcome (Gleeson et al. 2003).

Given the anti-apoptotic, mitogenic, and proliferating properties of GH and IGF1, the safety of the use of $\mathrm{GH}$ in childhood cancer survivors has been the subject of large-scale studies. The studies assessing the risk of tumor recurrence, largely confined to brain tumor survivors treated with $\mathrm{GH}$, have consistently reported no increased risk associated with $\mathrm{GH}$ replacement therapy (Swerdlow et al. 2000, Packer et al. 2001, Sklar et al. 2002). There was no evidence for an increased risk of disease recurrence or death following GH replacement therapy in a report from the CCSS on $361 \mathrm{GH}$-treated individuals, including 122 survivors of acute leukemia and 43 survivors of soft tissue sarcomas (Sklar et al. 2002). However, the data suggested that treatment with GH may slightly increase the risk of a secondary solid tumor, especially in survivors of acute leukemia. (Sklar et al. 2002). These suspicions were confirmed in an updated analysis of the same cohort after an additional 32 months of follow-up, in which the relative risk of survivors treated with
GH developing a second neoplasm was 2.15 (95\% confidence interval (CI) 1.3-3.5, $P<0.002$; Ergun-Longmire et al. 2006). In this updated analysis, meningiomas were the most common second neoplasms that were observed in survivors treated with GH. There was no association between dose and duration of GH therapy and this risk, and there was no difference in the risk of death in survivors treated with GH compared with survivors not treated so (Ergun-Longmire et al. 2006). Cancer survivors treated with GH may be at a higher risk of developing slipped epiphyses compared with children treated with GH for idiopathic GHD (Blethen \& Rundle 1996).

Adult GHD is now an established indication for GH therapy, given its association with metabolic derangements, such as increased body fat, raised plasma lipids, and decreased bone density and reduced quality of life (Link et al. 2004). Treatment with GH in adult survivors of childhood cancer seems to have a greater impact on quality of life and to result in more modest, although significant, improvements in the metabolic parameters (Murray et al. 2002, Mukherjee et al. 2005, Follin et al. 2006).

\section{Disorders of LH/FSH}

\section{Central precocious puberty}

Precocious puberty is defined as the onset of puberty before the age of 8 years in girls and 9 years in boys. CPP is due to the premature activation of the hypothalamic-pituitary-gonadal axis, and in girls, it 
can lead to the early onset of menstrual cycles, with menses occurring before the age of 10 years (Sigurjonssdottir \& Hayes 1968). Cranial irradiation at both lower doses (18-35 Gy) and higher doses ( $>35 \mathrm{~Gy}$ ) is associated with the development of CPP, by presumably disrupting inhibitory cortical influences (Brauner et al. 1984, Constine et al. 1993, Oberfield et al. 1996, Chow et al. 2008, Armstrong et al. 2009). In contrast, radiation doses $>50$ Gy are also associated with hypogonadotropic hypogonadism within the context of combined hormonal pituitary deficiencies (Lam et al. 1991, Constine et al. 1993, Armstrong et al. 2009). Risk factors associated with CPP following hypothalamic irradiation include female sex, young age at treatment, and increased BMI (Ogilvy-Stuart \& Shalet 1995, Oberfield et al. 1996).

In a report from the CCSS on CNS tumor survivors, early menarche (defined by the onset of menstrual cycles before 10 years of age) occurred in $14.5 \%$ of girls with a history of radiation to the hypothalamus-pituitary area, which was significantly more common than what was observed in siblings. Risk factors for early menarche included radiation before the age of 5 years or with doses $>50 \mathrm{~Gy}$ (Armstrong et al. 2009). The age-inappropriate sex steroid secretion can cause rapid bone age progression and further reduce the growth potential of children, most of whom carry additional risk factors for growth failure such as GHD and radiation-induced skeletal dysplasia.

In girls, precocious puberty is best characterized by the onset of sustained breast development before the age of 8 years (Sigurjonssdottir \& Hayes 1968). In boys, testicular volume, used to assess the onset of pubertal development in the general population, may not be a reliable indicator of puberty in childhood cancer survivors as chemotherapy and radiation can damage the seminiferous tubules, resulting in testes that are inappropriately small for a given stage of puberty. Thus, clinicians should be alerted by the early onset of other secondary sexual characteristics (e.g. pubic hair) prior to the age of 9 years. One of the first signs of pubertal development is an increase in the growth rate. In children who also are likely to have GHD, this may result in falsely reassuring 'normal' growth velocity, as mentioned previously.

Skeletal maturation can be assessed using the standard bone age (X-ray examination of the left wrist and hand) in order to estimate the individual's skeletal age (Greulich \& Pyle 1959). Advancement of the bone age more than 2 s.D. for chronological age is a consistent finding in children with precocious puberty. In girls with CPP, uterine growth on the pelvic ultrasound is a sign of estrogen stimulation, and is an earlier finding than bilaterally enlarged ovaries. Gonadotropin secretion is best assessed using the GnRH or GnRH agonist stimulation tests. An ample LH response, greater than the FSH response, indicates a pubertal pattern. The plasma estradiol levels in girls and testosterone levels in boys are also important indicators of pubertal development.

Delaying the progression of puberty in childhood cancer survivors with CPP results in the stabilization of the advancement of the bone age, and hence has been shown to improve the statural outcome, especially when contemporary regimens for $\mathrm{GH}$ replacement are used concurrently to treat GHD (Gleeson et al. 2003). Long-acting formulations of $\mathrm{GnRH}$ agonists are currently the treatment of choice when it is deemed clinically desirable to postpone pubertal progression.

\section{Hypogonadotropic hypogonadism}

Insufficient LH and FSH secretion has been reported in childhood cancer survivors. Deficits of LH and FSH secretion following irradiation of the hypothalamicpituitary region occur less often than GHD, and generally only occur following doses to the sellar region, $>30$ to $40 \mathrm{~Gy}$ (Sklar \& Constine 1995, Relander et al. 2000, Byrne et al. 2004, Armstrong et al. 2009, Green et al. 2009). In a report from the CCSS on survivors of childhood CNS tumors, late menarche (defined by the onset of menstrual cycles after 16 years of age) was used as a marker for hypogonadotropic hypogonadism, given that few patients were additionally exposed to alkylating agents (Table 1), known for their ovarian toxicity. In this study, late menarche was observed in $10.6 \%$ of the survivors, and was associated with doses of radiation $>50 \mathrm{~Gy}$, treatment after 10 years of age, and the diagnosis of medulloblastoma (Armstrong et al. 2009). In a recent report from the CCSS, female survivors with a history of exposure to doses of radiation $>30$ Gy to the hypothalamic-pituitary area were less likely to experience a pregnancy (Green et al. 2009).

In female ALL survivors, 'subtle' defects of gonadotropin secretion following radiation doses in the 18-24 Gy range have been described (Bath et al. 2001, Byrne et al. 2004); additional long-term follow-up data will provide a better sense of the ultimate effect of these lower doses of cranial irradiation on hypothalamic-pituitary-gonadal function. It is unclear whether chemotherapy alone can directly alter gonadotropin secretion (Bakker et al. 2004). 


\section{ACTH deficiency}

Apart from transient ACTH deficiency resulting from chronic suppression due to the prolonged use of pharmacologic doses of glucocorticoids, ACTH deficiency in childhood cancer survivors is relatively uncommon. It can be observed either as a result of direct tumoral impingement on the hypothalamicpituitary axis and surgery in that region, or following high-dose (>30 Gy) radiation (Rose et al. 2005, Patterson et al. 2009). In a study on children receiving treatment for CNS embryonal tumors that included high doses of radiation to the hypothalamicpituitary area (median dose $44 \mathrm{~Gy}$ ), the 4-year cumulative incidence of ACTH deficiency was 38\% (Laughton et al. 2008). As different investigators use different methods to establish a diagnosis of ACTH deficiency, comparison between studies can be difficult.

\section{TSH deficiency}

TSH deficiency, resulting in central hypothyroidism, occurs less often than GHD and CPP following the irradiation of the hypothalamic-pituitary area. It has been reported following doses $>30$ to 40 Gy (Sklar \& Constine 1995, Rose et al. 1999, Schmiegelow et al. 2003, Laughton et al. 2008). In a study on children receiving treatment for CNS embryonal tumors resulting in high doses of radiation to hypothalamuspituitary area, the cumulative incidence of TSH deficiency was $23 \%$ at 4 years with a significant risk for patients with doses to the hypothalamic-pituitary area above 42 Gy (Laughton et al. 2008). In contrast, a report by the CCSS on survivors of ALL suggested that cranial radiotherapy (doses $<30 \mathrm{~Gy}$ ) alone was insufficient to induce central hypothyroidism (Chow et al. 2009). There are few reports in the literature on the contribution of chemotherapy to the development of central hypothyroidism in childhood cancer survivors. Apart from one report suggesting a high incidence of patients with subtle TSH deficiency, as evidenced by the lack of nocturnal surge of TSH, most authors concur on the lack of association between chemotherapy and central hypothyroidism (Sanders et al. 1986, Van Santen et al. 2003, Bakker et al. 2004, Chow et al. 2009).

\section{Hyperprolactinemia}

High-dose hypothalamic irradiation, in the range of $50 \mathrm{~Gy}$ or greater, can be associated with hyperprolactinemia. Up to $75 \%$ of adult patients and $30 \%$ of pediatric patients had elevated baseline prolactin levels in a report on 32 patients who received high-dose cranial radiotherapy (39.6-70.2 Gy, with a mean $53.6 \mathrm{~Gy}$ ) as treatment for brain tumors (Constine et al. 1993).

\section{Disorders of the thyroid}

Abnormalities of the thyroid gland are among the most frequent endocrine complications that are observed in childhood cancer survivors (Table 4). Early recognition and treatment of thyroid dysfunction are crucial in this population, given the importance of thyroid hormones for normal growth and development during childhood.

\section{Therapy-induced primary hypothyroidism}

Primary hypothyroidism is the most frequently observed thyroid disorder following exposure of the gland to radiation. This exposure can occur in individuals treated with the following types of radiation: neck/mantle irradiation for Hodgkin's lymphoma; craniospinal irradiation for brain tumors; or TBI for cytoreduction before HSCT (Chin et al. 1997, Brennan et al. 1998, Sklar et al. 2000a,b, Van Santen et al. 2003, Chow et al. 2009, Laughton et al. 2008). Primary hypothyroidism has also been described in individuals treated with radiolabeled agents such as ${ }^{131}$ I-metaiodobenzylguanidine (Picco et al. 1995) and ${ }^{131}$ I-labeled monoclonal antibody for neuroblastoma (Laverdiére et al. 2005). Chemotherapy alone does not seem to be associated with an increased incidence of primary hypothyroidism (Metzger et al. 2006a,b, Chow et al. 2009). The prevalence of hypothyroidism is primarily determined by the total dose of radiation to the thyroid and by the duration of follow-up (Fig. 1). Additional risk factors for developing hypothyroidism include female gender, white race, and age $>15$ years at the time of diagnosis (Sklar et al. 2000a,b, Metzger et al. 2006a,b). In a large study from the CCSS on young adult survivors of Hodgkin's lymphoma, a cumulative incidence of hypothyroidism of $28 \%$ was observed; for those treated with doses $>45 \mathrm{~Gy}$, there was a $50 \%$ incidence of hypothyroidism 20 years after diagnosis (Sklar et al. 2000a,b). By contrast, in a study from the CCSS on thyroid dysfunction in ALL survivors, the cumulative incidence of hypothyroidism was only $1.6 \%$, which was, nonetheless, significantly higher than that in the cohort of siblings (Chow et al. 2009). Survivors who received $>20 \mathrm{~Gy}$ cranial radiation plus any spinal radiotherapy had the highest risk for developing hypothyroidism. Interestingly, the time interval between the diagnosis of cancer and that of hypothyroidism was notably more prolonged 
Table 4 Therapy-related complications affecting the thyroid

\begin{tabular}{|c|c|c|}
\hline Complication & Therapy-related risks & $\begin{array}{l}\text { Relationship to time, dose to the thyroid } \\
\text { when applicable, and available cumulative } \\
\text { incidence data }\end{array}$ \\
\hline Hypothyroidism & $\begin{array}{l}\text { Radiotherapy to neck }{ }^{131} \text { I-labeled } \\
\text { agents such as MIBG }\end{array}$ & $\begin{array}{l}\text { Hodgkin's lymphoma survivors: cumulative } \\
\text { incidence } 28 \% \text {, reaches } 50 \% \text { for doses } \\
>45 \text { Gy over } 20 \text { years } \\
40-80 \% \text { within } 2 \text { years of exposure }\end{array}$ \\
\hline Hyperthyroidism & Radiotherapy to neck & $\begin{array}{l}\text { Doses }>35 \text { Gy, cumulative incidence } 5 \% \text { over } \\
25 \text { years }\end{array}$ \\
\hline Autoimmune disease & HSCT & $\begin{array}{l}\text { By transfer of abnormal clones of B- or T-cells } \\
\text { from donor to host }\end{array}$ \\
\hline Cancer & Radiotherapy to neck & $\begin{array}{l}\text { Doses up to } 20-29 \text { Gy range. Cumulative } \\
\text { incidence } 18 \% \\
\text { Patients treated }<10 \text { years of age at higher risk } \\
\text { Median latency exceeds } 20 \text { years }\end{array}$ \\
\hline
\end{tabular}

${ }^{131}$ I-MIBG, iodine-131-metaiodobenzylguanidine; HSCT, hematopoietic stem cell transplantation.

in survivors of ALL ( $>10$ years) compared with survivors of Hodgkin's disease (Chow et al. 2009). As hypothyroidism can occur more than 25 years following the completion of cancer treatments, it is imperative that individuals at risk undergo lifelong surveillance.

\section{Therapy-induced hyperthyroidism}

Hyperthyroidism occurs less frequently than hypothyroidism in childhood cancer survivors. It is diagnosed most often following external beam radiation to the neck for Hodgkin's lymphoma. In a large study from the CCSS that included more than 1700 survivors of Hodgkin's lymphoma, survivors were eight times more likely to develop hyperthyroidism compared with siblings (Sklar et al. 2000a,b). The only identified risk factor for the development of hyperthyroidism was exposure to doses $>35 \mathrm{~Gy}$ to the thyroid (Sklar et al. 2000a,b). In a recent CCSS report on thyroid dysfunction in ALL survivors, the cumulative incidence of hyperthyroidism was $0.6 \%$, which was much lower than the incidence of hypothyroidism but still higher than the incidence observed in the control population of siblings. The greatest risk was seen in those in whom the absorbed dose to the thyroid exceeded 15 Gy (Chow et al. 2009).

\section{Autoimmune thyroid disease}

There are several reports of the occurrence of autoimmune thyroid disease in allogeneic HSCT recipients (Sklar et al. 2001, Au et al. 2005). The adoptive transfer of abnormal clones of T- or B-cells from donor to recipient could be responsible for these observations. Hypothyroidism with or without a preceding hyperthyroid phase was observed in subjects with positive thyroglobulin autoantibody (Au et al. 2005). Hyperthyroidism with positive TSH receptor autoantibodies has also been reported following allogeneic HSCT (Sklar et al. 2001).

\section{Thyroid neoplasms}

The exposure of the thyroid to either direct or scatter (for example, after prophylactic CNS irradiation in patients treated for ALL) radiation is a significant risk factor for thyroid neoplasms, benign and malignant.

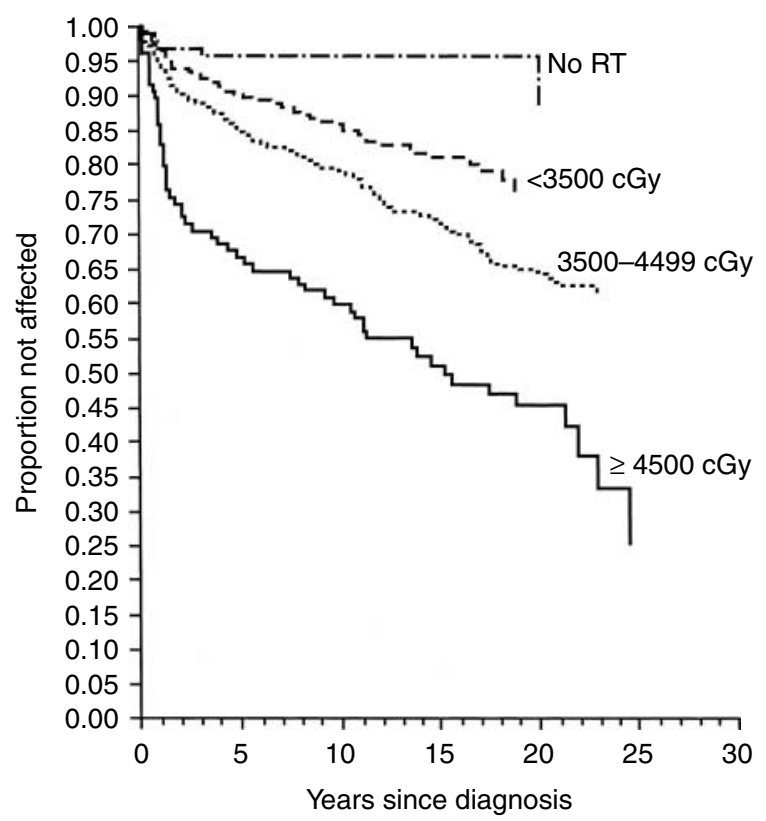

Figure 1 Probability of developing an underactive thyroid after diagnosis of Hodgkin's lymphoma. Patients are grouped according to dose of thyroid irradiation. Reprinted with permission, Sklar et al. (2000a). Copyright 2000, The Endocrine Society. 
Children treated before 10 years of age and/or with doses in the range of 20-29 Gy appear to be at the greatest risk for the development of thyroid cancer. The association between thyroid irradiation and thyroid neoplasms is linear at low doses of radiation, but shows a downward turn at doses above $30 \mathrm{~Gy}$, with a risk that remains, nevertheless, elevated compared with the general population (Sigurdson et al. 2005). In a recent report from the British CCSS, the standardized incidence ratio for thyroid cancer was 18.0 (95\% CI 13.4-23.8), with the highest risk being observed in survivors of Hodgkin's lymphoma (Taylor et al. 2009). The majority of cancers were differentiated carcinomas (i.e. papillary and follicular) with a median latency of 20.8 years, similar to data published from the CCSS (Sklar et al. 2000a,b, Sigurdson et al. 2005, Taylor et al. 2009).

In general, postirradiation thyroid cancers behave in a non-aggressive fashion, similar to what is observed in de novo thyroid cancers among the young (Acharya et al. 2003). The pathogenesis of radiation-induced thyroid neoplasms is felt to be related to rearrangements of rearranged in transformation-papillary thyroid carcinomas (RET/PTC) gene induced by the exposure to radiation (Bounacer et al. 1997, Elisei et al. 2001). Thyroid neoplasms following radiotherapy may not become evident for many years after exposure to radiation; therefore, all individuals at risk require lifelong follow-up (Sklar et al. 2000a,b, Acharya et al. 2003, Chow et al. 2009). While thyroid ultrasound screening has been recommended by some groups (Brignardello et al. 2008), it may lead to unnecessary and invasive procedures, and has not been shown to reduce morbidity or mortality in this population (Metzger et al. 2006a,b).

\section{Gonadal dysfunction}

In addition to the derangements related to gonadotropin secretion, childhood cancer survivors are at risk of gonadal dysfunction related to a direct insult to the testes or ovaries (Table 5).

\section{Males}

The human testis combines two functions: sex steroid production and sperm production. Although interconnected, these functions are under separate controls. These include a multitude of endocrine, paracrine, and autocrine factors (Griffin \& Wilson 1992). In the testis, germ cells ultimately form sperm; Sertoli cells support and nurture the developing germ cells, and are also the site of production of inhibin; and interstitial
Leydig cells are responsible for the biosynthesis of testosterone. These three cell types are organized into two functional compartments: germ cells and Sertoli cells form the seminiferous tubules where spermatogenesis takes place, and the network of Leydig cells which are responsible for the production of testosterone. Leydig cells lie in proximity to the basal compartment of the seminiferous tubules, where they can deliver high concentrations of testosterone, which are necessary for normal spermatogenesis. Despite their interconnection, these two functional compartments are affected in different ways by cancer treatments.

\section{Leydig cell dysfunction}

Treatment-induced Leydig cell failure and testosterone insufficiency are relatively uncommon compared with germ dysfunction and infertility following cancer treatments. Leydig cell failure will result in delayed/ arrested puberty and lack of secondary sexual characteristics if it occurs before the onset of puberty. If it occurs following the completion of normal pubertal development, it can result in reduced libido, erectile dysfunction, decreased bone mineral density (BMD), decreased muscle mass, and other metabolic disturbances (Sklar 1999). Raised plasma concentrations of LH combined with low levels of testosterone are characteristic of Leydig cell dysfunction, but these changes may not become apparent until the individual has reached mid-adolescence (Shalet et al. 1985). Thus, it can be very difficult to assess or predict Leydig cell function in the preadolescent males.

With their slow rate of turnover, Leydig cells are less vulnerable to damage from cancer therapy than germ cells, and chemotherapy-induced Leydig cells requiring testosterone replacement therapy are rare (Blatt et al. 1981, Sklar 1999). Nonetheless, Leydig cell dysfunction may be observed following treatment with alkylating agent regimens, with some reports indicating that from 10 to $57 \%$ of male subjects can develop elevated serum concentrations of LH following treatment (Bramswig et al. 1990, Siimes et al. 1995, Heikens et al. 1996, Mackie et al. 1996, Papadakis et al. 1999, Sklar 1999, Relander et al. 2000, Kenney et al. 2001, Romerius et al. 2009). When it does occur, chemotherapy-induced Leydig cell dysfunction is generally subclinical (Afify et al. 2000, Bakker et al. 2004, Sanders 2004).

By contrast, Leydig cells are more vulnerable to radiation-induced damage. The interpretation of the impact of radiation on Leydig cell function is confounded by the concurrent use of chemotherapy in 
Table 5 Therapy-related complications affecting the gonads

\begin{tabular}{|c|c|c|}
\hline Complication & Therapy-related risks & $\begin{array}{l}\text { Relationship to time, dose to the gonads when applicable, } \\
\text { and available cumulative incidence data }\end{array}$ \\
\hline \multicolumn{3}{|l|}{ Testes } \\
\hline \multirow[t]{3}{*}{ Leydig cell dysfunction } & Alkylating agents & Generally subclinical. Cumulative incidence $10-57 \%$ \\
\hline & Radiotherapy & Doses > 24 Gy \\
\hline & & Cumulative incidence $50 \%$ for doses $>33$ Gy \\
\hline \multirow[t]{4}{*}{ Germ cell failure } & Alkylating agents & Cyclophosphamide doses $>10 \mathrm{~g} / \mathrm{m}^{2}$ \\
\hline & Radiotherapy & Doses $>0.15$ Gy: possible risk \\
\hline & & Doses $>2$ Gy high risk \\
\hline & & In combination, cumulative risk $40-60 \%$ \\
\hline \multicolumn{3}{|l|}{ Ovaries } \\
\hline \multirow[t]{2}{*}{ Acute ovarian failure } & Alkylating agents & Higher risk for older age at exposure \\
\hline & Radiotherapy to the ovaries & Radiotherapy dose > 20 Gy: cumulative incidence $70 \%$ \\
\hline Premature menopause & Alkylating agents & $\begin{array}{l}\text { Higher risk for older age at exposure } \\
\text { In combination, cumulative risk } 30 \%\end{array}$ \\
\hline
\end{tabular}

most subjects as well as by the potential effects of the malignancy itself (e.g. testicular relapse in ALL). Leydig cell failure, nevertheless, occurs at doses of radiation higher than those associated with germ cell dysfunction. The likelihood of sustaining radiationinduced Leydig cell failure is directly related to the dose delivered and inversely related to age at treatment (Leiper et al. 1986, Shalet et al. 1989, Sarafoglou et al. 1997). Normal amounts of testosterone are produced by the majority of males who receive $<20$ Gy fractionated radiation to the testes (Sklar 1999). A dose $>24$ Gy of fractionated irradiation as therapy for young males with testicular relapse of ALL is associated with a very high risk for Leydig cell dysfunction. The majority of boys who are prepubertal at the time they receive $24 \mathrm{~Gy}$ testicular irradiation will develop Leydig cell failure and require androgen replacement (Shalet et al. 1985, Leiper et al. 1986). Testicular doses in excess of $33 \mathrm{~Gy}$ have been associated with Leydig cell failure in $50 \%$ of adolescent and young adult men (Izard 1995).

\section{Germ cell dysfunction}

The sperm-producing cells are more vulnerable to cancer treatments than Leydig cells, and are frequently impaired by radiotherapy and several types of chemotherapy. Germ cell dysfunction with resultant infertility is often associated with reduced testicular volume, increased FSH concentrations, and reduced plasma concentrations of inhibin B (Lewis \& Lee 2009). However, for clinical purposes and counseling, assessing male fertility requires obtaining a sperm count as none of these aforementioned surrogate markers has sufficient specificity or sensitivity to predict outcome for an individual subject (Andreu et al. 2000, Kenney et al. 2001).
The chemotherapeutic agents most commonly associated with impaired male fertility are alkylating agents (Table 1). Impaired fertility occurs in 40-60\% of young adult survivors of childhood cancer, and young age at exposure does not seem to be protective, as previously thought (Kenney et al. 2001). A high probability of oligospermia, azoospermia, and infertility is associated with doses of cyclophosphamide $>20 \mathrm{~g} / \mathrm{m}^{2}$. In contrast, many individuals treated with a cumulative dose of $7.5-10 \mathrm{~g} / \mathrm{m}^{2}$ or less retain normal sperm production (Relander et al. 2000, Kenney et al. 2001). Procarbazine, another alkylating agent commonly used in the treatment of Hodgkin's lymphoma, has also been shown to induce impaired sperm production in a dose-dependent fashion. Patients with Hodgkin's lymphoma and who received three mechlorethamine, vincristine, procarbazine, and prednisone (MOPP) cycles alternating with three cycles of doxorubicin hydrochloride, bleomycin, vinblastine, and dacarbazine seemed to suffer less testicular damage than patients who received six MOPP cycles (Mackie et al. 1996, van den Berg et al. 2004). Most of the young men treated with the combination of busulfan and cyclophosphamide in preparation for HSCT do appear to sustain damage to their germinal epithelium, with possible recovery for patients treated at lower doses $(120 \mathrm{mg} / \mathrm{kg}$ for cyclophosphamide and $16 \mathrm{mg} / \mathrm{kg}$ for busulfan; Grigg et al. 2000, Anserini et al. 2002).

Impaired sperm production can occur at doses of radiation as low as $0.15 \mathrm{~Gy}$. If the dose is under 1-2 Gy, recovery is common. At doses $>2$ to $3 \mathrm{~Gy}$, recovery of sperm production is rare (Meistrich et al. 1997). Germ cell dysfunction is present in essentially all males treated with TBI (Sanders et al. 1996). Azoospermia is the rule for patients studied in the first few years after treatment with TBI. Recovery of germ 
cell function has occurred rarely and primarily following single-dose irradiation (Sklar et al. 1984, Sanders et al. 1996). Given the high rate of impaired sperm production in survivors, sperm banking should be offered to all adolescent males prior to the initiation of cancer therapy, whenever clinically feasible.

\section{Females}

The sex steroid-producing cells and oocytes are functionally and structurally interdependent within the ovarian follicle. As a result, when ovarian failure occurs, both sex hormone production and fertility are disrupted (Sklar 1999). Older age is an important risk factor for ovarian failure following childhood cancer and its treatments, given the progressive decline in oocyte reserve with increasing age (Sklar 1999). If ovarian function is lost prior to the onset of puberty, it will result in delayed puberty and primary amenorrhea. If ovarian function is lost during or after pubertal maturation, one generally observes arrested puberty, secondary amenorrhea, and menopausal symptoms (i.e. hot flashes and vaginal dryness). Women who experience premature loss of estrogen production are also predisposed to developing osteoporosis and coronary artery disease (Aisenberg et al. 1998). Increased plasma concentrations of gonadotropins, especially $\mathrm{FSH}$, and reduced levels of estradiol are typically found in the adolescent and young adults with ovarian failure. These markers cannot be used in younger children as gonadotropins are often normal despite ovarian damage (Carr 1992).

The loss of ovarian function owing to exposure to cancer treatments can occur either early (during or immediately following the completion of treatment with the so-called acute ovarian failure (AOF)), or many years after the completion of cancer therapy but prior to the age of 40 years (the so-called premature menopause; Chemaitilly et al. 2006, Sklar et al. 2006). The incidence of AOF was $6.3 \%$ in a report from the CCSS (Chemaitilly et al. 2006), whereas the cumulative incidence of premature menopause was $8 \%$, ten times higher than that observed in sibling controls (Sklar et al. 2006).

Owing to a greater follicular reserve, the ovaries of prepubertal girls are more resistant to chemotherapyinduced damage when compared with the ovaries of adults (Carr 1992, Grigg et al. 2000, Chemaitilly et al. 2006; Fig. 2). Nevertheless, certain chemotherapeutic agents, especially alkylating agents (Table 1), when given at high doses can cause ovarian failure, even in younger subjects (Rivkees \& Crawford 1988, Wallace

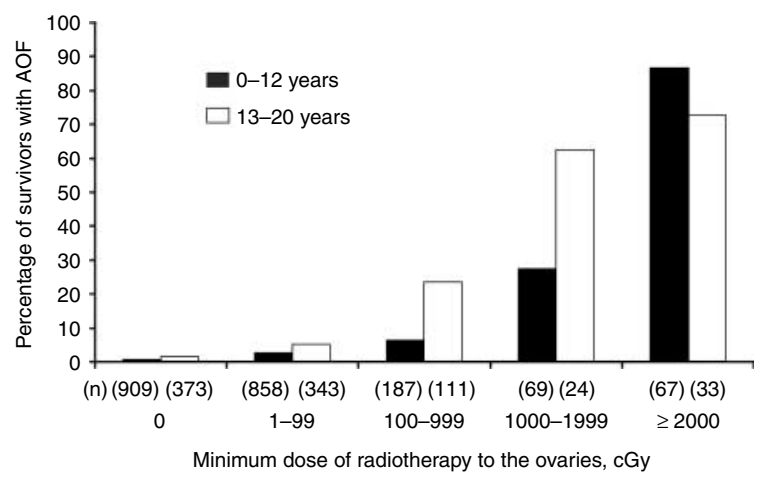

Figure 2 Percentage of subjects with acute ovarian failure (AOF) according to age at diagnosis. Ages of 0-12 years (solid bar) and 13-20 years (striped bar) versus dose of radiation to the ovary. Reprinted with permission, Chemaitilly et al. (2006). Copyright 2006, The Endocrine Society.

et al. 1989b, Chemaitilly et al. 2006, Sklar et al. 2006). In a report from the CCSS, older age at treatment and exposure to procarbazine at any age and to cyclophosphamide at ages 13-20 years were independent risk factors for AOF (Chemaitilly et al. 2006). Females who receive high-dose myeloablative therapy with alkylating agents such as busulfan, melphalan, and thiotepa in preparation for HSCT are at high risk of developing ovarian failure (Michel et al. 1997). This has been observed in patients treated both before and after pubertal development. Recovery of function has been recorded only rarely, but the follow-up time has been relatively brief for most of the patients (Thibaud et al. 1998). However, the majority of prepubertal girls and adolescents receiving standard chemotherapy will fortunately maintain or recover ovarian function during the immediate posttreatment period (Horning et al. 1981, Hudson et al. 1993, Sklar 1999). Histologic examination of ovarian tissue in prepubertal and postpubertal girls treated for solid tumors or leukemia has nevertheless revealed a decreased number of ovarian follicles and inhibition of follicular growth compared with age-matched controls (HimelsteinBraw et al. 1978, Larsen et al. 2003). Thus, it is not surprising that among women who do retain or recover function following treatment with standard doses of alkylating agents, a subset will experience premature menopause when they reach their 20s and 30s (Byrne et al. 1992, Nasir et al. 1997, Papadakis et al. 1999, Sklar 1999, Sklar et al. 2006).

In a report from the CCSS, female survivors with a history of exposure to high doses of alkylating agents, to lomustine or to cyclophosphamide were less likely to experience a pregnancy when compared with sibling controls (Green et al. 2009). When female childhood 
cancer survivors treated with chemotherapy did get pregnant, no adverse pregnancy outcomes were identified in a large study conducted within the framework of the CCSS (Green et al. 2002).

Females receiving abdominal, pelvic, or spinal irradiation are at increased risk of ovarian failure, especially if both ovaries were within the treatment field (Horning et al. 1981, Damewood \& Grochow 1986, Hamre et al. 1987, Clayton et al. 1989, Wallace et al. 1989a, Thibaud et al. 1992, Sklar et al. 2006, Chow et al. 2008). However, when ovarian transposition is performed prior to radiotherapy, ovarian function is retained in the majority of young girls and adolescent females (Thibaud et al. 1992, Sklar 1999). While radiation doses of $6 \mathrm{~Gy}$ may be sufficient to produce irreversible ovarian damage in women $>40$ years of age, doses in the range of 10-20 Gy are needed to induce permanent ovarian failure in the majority of females treated during childhood (Wallace et al. 1989a, Thibaud et al. 1992). In a report from the CCSS, radiation doses to the ovary $>20$ Gy were associated with the highest rate of AOF (70\%), with higher rates in older individuals (13-20 years) when compared with those who were younger ( $0-12$ years) at the time of treatment (Chemaitilly et al. 2006). Moreover, if radiation is being given in association with alkylating agent chemotherapy, ovarian dysfunction may occur despite the use of lower doses. In a report from the CCSS on premature menopause, while both radiation to the ovaries and exposure to alkylating agents were independent risk factors, the cumulative incidence of premature menopause in individuals treated with both alkylating agents and abdominalpelvic radiation was in the range of $30 \%$ (Sklar et al. 2006). In a report from the CCSS, survivors treated with radiotherapy doses $>5 \mathrm{~Gy}$ to the ovaries/uterus were less likely to experience a pregnancy when compared with sibling controls (Green et al. 2009).

The outcome of ovarian function following TBI appears to be determined to a large extent by the age of the patient at the time of irradiation. Approximately $50 \%$ of prepubertal girls given fractionated TBI will enter puberty spontaneously and achieve menarche at a normal age (Sarafoglou et al. 1997, Matsumoto et al. 1999). Ovarian failure is seen in essentially all patients who are aged $>10$ years at the time they are treated with TBI (Sanders et al. 1988, Matsumoto et al. 1999). Recovery of ovarian function has, nevertheless, been documented in a small number of women who have received TBI (Sanders et al. 1996). These women had increased risks of miscarriage and premature delivery of low-birth weight infants. This can be due to the uterine consequences of TBI (Sanders et al. 1996,
Bath et al. 1999, Holm et al. 1999, Matsumoto et al. 1999, Larsen et al. 2004).

\section{Bone density and risk of osteoporosis}

Childhood cancer survivors as a group have reduced $\mathrm{BMD}$, and are at an increased risk for osteopenia, osteoporosis, and fractures (Aisenberg et al. 1998, Sala \& Barr 2007, Wasilewski-Masker et al. 2008). This is the result of mainly three factors: the primary disease itself (Crofton et al. 1998); exposure to glucocorticoids and other chemotherapeutic agents such as methotrexate (De Boer et al. 1994, Stanislavejic \& Babcock 1997, Brennan et al. 1999, Sala \& Barr 2007, Wasilewski-Masker et al. 2008); and the hormonal deficiencies associated with cancer and its treatments (and described earlier in the text), GHD and sex hormone deficiencies (Aisenberg et al. 1998, Nysom et al. 2000, Sala \& Barr 2007, Wasilewski-Masker et al. 2008). Fractures were shown to occur in up to $39 \%$ of children during treatment for ALL (Halton et al. 1996). Although BMD improves after the completion of treatment, childhood cancer survivors remain at in increased risk of osteopenia long term (Thomas et al. 2008, Wasilewski-Masker et al. 2008). Genetic predisposition (such as CRHR1 polymorphisms) may increase the risk of low BMD, especially following exposure to glucocorticoids or methotrexate (Jones et al. 2008).

Subjects deemed at high risk for the development of osteoporosis should undergo periodic bone density studies (Wasilewsi-Masker et al. 2008). While dual energy X-ray absorptiometry (DEXA) remains the most widely used tool for measuring BMD, its results should be interpreted according to age, pubertal stage, and height in the pediatric population using $z$-scores not $T$-scores. Failure to take these elements into account may result in an over-diagnosis of osteoporosis during childhood and adolescence (Nysom et al. 2000, Gafni \& Baron 2004). Preventive measures (for example, supplementation with calcium and vitamin $\mathrm{D}$, smoking cessation, and weight-bearing exercise) should be encouraged in all individuals with low or borderline BMD. In addition, sex hormone replacement therapy and $\mathrm{GH}$ replacement are useful in improving BMD in subjects with known deficiencies.

\section{Overweight, obesity, and disorders of glucose homeostasis}

Obesity and being overweight are often observed in survivors of acute leukemia and various brain tumors (Sklar et al. 2000a,b). Risk factors for obesity include 
cranial irradiation, female gender, and exposure to dexamethasone. The deleterious effects of dexamethasone on body composition may be temporary (van der Sluis et al. 2002). A report from the CCSS found that cranial radiotherapy $>20 \mathrm{~Gy}$, especially in females treated at a young age $(<4$ years), was significantly associated with obesity (i.e. BMI $>30$; Oeffinger et al. 2003). In a more recent study that examined change in BMI over time in the same cohort of ALL survivors, female gender, treatment at a young age, and cranial radiotherapy were associated with a more rapid rate of BMI increase (Garmey et al. 2008). Within the CCSS cohort, female survivors with a BMI above $25 \mathrm{~kg} / \mathrm{m}^{2}$ were more likely to be homozygous for a polymorphism of the leptin receptor (Arg allele at Gln $223 \mathrm{Arg}$ ) that has been associated with obesity in the general population than female survivors with a BMI below $25 \mathrm{~kg} / \mathrm{m}^{2}$. The difference is particularly significant in survivors treated with cranial radiotherapy; females having this particular polymorphism were six times more likely to become obese (Ross et al. 2004). This observation underscores the importance of genetic susceptibility to the toxic effects of the therapeutic exposures routinely used to treat children with cancer (Armenian \& Bhatia 2009).

GHD in adulthood has been associated with obesity, and may contribute to the observed changes in body composition in ALL survivors who received high-dose cranial radiotherapy (Talvensaari et al. 1996). Childhood ALL survivors have also been shown to have reduced physical activity, even many years after the completion of cancer therapy, but the contribution of this behavioral factor to the development of obesity remains uncertain (Reilly et al. 1998). Premature adiposity rebound, believed to be a predictor of adult obesity, was also described in childhood ALL survivors, and may partly explain the increased risk for obesity in patients treated at a very young age ( $<5$ years; Reilly et al. 2001).

Brain tumors developing near the sellar region and their treatments (e.g. surgery and radiation) can also disrupt hypothalamic and pituitary functions and induce states of morbid obesity (Lustig et al. 2003a,b). While a hypothalamic insult has been hypothesized to alter satiety centers and cause hyperphagia, another mechanism involving an increased parasympathetic tone leading to hyperinsulinemia (the latter promoting fat storage) has been suggested as a contributing factor to obesity in these patients. It is with regard to the latter mechanism that treatment with octreotide has been tried in a small number of patients with hypothalamic obesity, and it has yielded some encouraging results (Lustig et al. 2003b). Dextroamphetamine has also been used with some success in order to control weight gain in patients with obesity related to hypothalamic injury (Mason et al. 2002).

Childhood cancer survivors are at an increased risk of developing diabetes mellitus. In a report from the CCSS, survivors were almost twice as likely to report diabetes when compared with siblings. The main risk factors detected in this study were exposure to TBI, abdominal radiation, and alkylating agents (Table 1; Meacham et al. 2009). Disorders of glucose homeostasis have indeed been shown to occur in pediatric HSCT recipients, especially those treated with TBI. The primary abnormality seems to be increased resistance to insulin (Lorini et al. 1995, Taskinen et al. 2000, Hoffmeister et al. 2004, d'Annunzio et al. 2005, Neville et al. 2006, Baker et al. 2007, Chemaitilly et al. 2009). More studies are needed in order to elucidate the mechanisms through which TBI alters insulin sensitivity, and to define the best approach in managing this disorder.

\section{Summary}

Childhood cancer survivors have an increased risk of endocrine disease affecting many areas: hypothalamicpituitary function, gonadal and reproductive function, thyroid function, body composition, and glucose homeostasis. The major risk factors include radiation therapy to key endocrine organs and exposure to alkylating agents. These endocrine abnormalities may evolve over many years. One of the future challenges will be to better characterize the role of genetic variability in the pathogenesis of these endocrine abnormalities. Early recognition and treatment can reduce morbidity and mortality in this vulnerable population. The importance of long-term surveillance of those at risk cannot be overemphasized.

\section{Declaration of interest}

Dr Sklar has served as a consultant for EMD Serono. Dr Chemaitilly has no financial conflicts to declare.

\section{Funding}

This review was not supported by a grant from any funding agency in the public, commercial, or not-for-profit sector.

\section{References}

Acharya S, Sarafoglou K, LaQuaglia M, Lindsley S, Gerald W, Wollner N, Tan C \& Sklar C 2003 Thyroid neoplasms after therapeutic radiation of malignancies during childhood or adolescence. Cancer 97 2397-2403. 
Adan L, Sainte-Rose C, Souberbielle JC, Zucker JM, Kalifa C \& Brauner R 2000 Adult height after growth hormone (GH) treatment for GH deficiency due to cranial irradiation. Medical and Pediatric Oncology 34 14-19.

Afify A, Shaw PJ, Clavano-Harding A \& Cowell CT 2000 Growth and endocrine function in children with acute myeloid leukemia after bone marrow transplantation using busulfan/cyclophosphamide. Bone Marrow Transplantation 25 1087-1092.

Aisenberg J, Hsieh K, Kalaitzoglou G, Whittam E, Heller G, Schneider R \& Sklar C 1998 Bone mineral density (BMD) in long-term survivors of childhood cancer. Journal of Pediatric Hematology/Oncology 20 241-245.

Andreu JAL, Fernandez PJ, i Tortajada JF, Navarro I, Rodriguez-Ineba A, Antonio P, Muro MD \& Romeu A 2000 Persistent altered spermatogenesis in long-term childhood cancer survivors. Pediatric Hematology and Oncology 17 21-30.

Anserini P, Chiodi S, Spinelli S, Costa M, Conte N, Copello F \& Bacigalupo A 2002 Semen analysis following allogeneic bone marrow transplantation. Additional data for evidence-based counselling. Bone Marrow Transplantation 30 447-451.

Armenian SH \& Bhatia S 2009 Chronic health conditions in childhood cancer survivors: is it all treatment-related - or do genetics play a role? Journal of General Internal Medicine 24 S395-S400.

Armstrong GT, Whitton JA, Gajjar A, Kun LE, Chow EJ, Stovall M, Leisenring W, Robison LL \& Sklar CA 2009 Abnormal timing of menarche in survivors of central nervous system tumors. A report from the Childhood Cancer Survivor Study. Cancer 115 2562-2570.

Au WY, Lie AK, Kung AW, Liang R, Hawkins BR \& Kwong YL 2005 Autoimmune thyroid dysfunction after hematopoietic stem cell transplantation. Bone Marrow Transplantation 35 383-388.

Baker KS, Ness KK, Steinberger J, Carter A, Francisco L, Burns LJ, Sklar C, Forman S, Weisdorf D, Gurney JG et al. 2007 Diabetes, hypertension and cardiovascular events in survivors of hematopoietic stem cell transplantation: a report from the bone marrow transplant survivor study. Blood 109 1765-1772.

Bakker B, Oostdijk W, Bresters D, Walenkamp MJ, Vossen JM \& Wit JM 2004 Disturbances of growth and endocrine function after busulfan-based conditioning for haematopoeitic stem cell transplantation during infancy and childhood. Bone Marrow Transplantation 33 1049-1056.

Bath LE, Critchley HOD, Chambers SE, Anderson RA, Kelnar CJ \& Wallace WH 1999 Ovarian and uterine characteristics after total body irradiation in childhood and adolescence: response to sex steroid replacement. British Journal of Obstetrics and Gynaecology 106 1265-1272.

Bath LE, Anderson RA, Critchley HOD, Kelnar CJ \& Wallace WH 2001 Hypothalamic-pituitary-ovarian dysfunction after prepubertal chemotherapy and cranial irradiation for acute leukaemia. Human Reproduction 16 1838-1844.

van den Berg $\mathrm{H}$, Furstner F, van den Bos C \& Begrendt $\mathrm{H}$ 2004 Decreasing the number of MOPP courses reduces gonadal damage in childhood Hodgkin's disease. Pediatric Blood \& Cancer 42 210-215.

Björk J, Link K \& Erfurth EM 2005 The utility of the growth hormone $(\mathrm{GH})$ releasing hormone-arginine test for diagnosing GH deficiency in adults with childhood acute lymphoblastic leukemia treated with cranial irradiation. Journal of Clinical Endocrinology and Metabolism 90 6048-6054.

Blatt J, Poplack DG \& Sherins RJ 1981 Testicular function in boys after chemotherapy for acute lymphoblastic leukemia. New England Journal of Medicine 304 1121-1124.

Blethen SL \& Rundle AC 1996 Slipped capital femoral epiphyses in children treated with growth hormone. A summary of the natural cooperative growth experience. Hormone Research 46 113-116.

Bounacer A, Wicker R, Caillou B, Cailleux AF, Sarasin A, Schlumberger M \& Suarez HG 1997 High prevalence of activating ret proto-oncogene rearrangements, in thyroid tumors from patients who had received external radiation. Oncogene 15 1263-1276.

Bramswig JH, Heimes U, Heiermann E, Schlegel W, Nieschlag E \& Schellong G 1990 The effect of different cumulative doses of chemotherapy on testicular function. Cancer 65 1298-1302.

Brauner R, Czernichow P \& Rappaport R 1984 Precocious puberty after hypothalamic and pituitary irradiation in young children. New England Journal of Medicine 311920.

Brauner R, Fontoura M, Zucker JM, Devergie A, Souberbielle JC, Prevot-Saucet C, Michon J, Gluckman E, Griscelli C, Fischer A et al. 1993 Growth and growth hormone secretion after bone marrow transplantation. Archives of Disease in Childhood 64 458-463.

Brennan BM, Rahim A, Mackie EM, Eden OB \& Shalet SM 1998 Growth hormone status in adults treated for acute lymphoblastic leukaemia in childhood. Clinical Endocrinology 48 777-783.

Brennan BMD, Rahim A, Adams JA, Eden OB \& Shalet SM 1999 Reduced bone mineral density in young adults following cure of acute lymphoblastic leukaemia in childhood. British Journal of Cancer 79 1859-1863.

Brignardello E, Corrias A, Isolato G, Palestini N, Cordero di Montezemolo L, Fagioli F \& Boccuzzi G 2008

Ultrasound screening for thyroid carcinoma in childhood cancer survivors: a case series. Journal of Clinical Endocrinology and Metabolism 93 4840-4843.

Brownstein CM, Mertens AC, Mitby PA, Stovall M, Qin J, Heller G, Robison LL \& Sklar CA 2004 Factors that affect final height and change in height standard deviation scores in survivors of childhood cancer treated with growth hormone: a report from the Childhood Cancer Survivor Study. Journal of Clinical Endocrinology and Metabolism 89 4422-4427. 
Byrne J, Fears TR, Gail MH, Pee D, Connelli RR, Austin DF, Holmes GF, Holmes FF, Latourette HB, Meigs JW et al. 1992 Early menopause in longterm survivors of cancer during adolescence. American Journal of Obstetrics and Gynecology 166 788-793.

Byrne J, Fears TR, Mills JL, Zeltzer LK, Sklar C, Meadows AT, Reaman GH \& Robison LL 2004 Fertility of longterm male survivors of acute lymphoblastic leukemia diagnosed during childhood. Pediatric Blood \& Cancer 42 364-372.

Carr BR 1992 Disorders of the ovary and the reproductive tract. In WIlliams Textbook of Endocrinology, vol 8, pp 733-798. Eds JD Wilson \& DW Foster. Philadelphia: W.B. Saunders.

Chemaitilly W, Trivin C, Souberbielle JC \& Brauner R 2003 Assessing short statured children for growth hormone deficiency. Hormone Research 60 34-42.

Chemaitilly W, Mertens AC, Mitby P, Whitton J, Stovall M, Yasui Y, Robison LL \& Sklar CA 2006 Acute ovarian failure in the childhood cancer survivor study. Journal of Clinical Endocrinology and Metabolism 91 1723-1728.

Chemaitilly W, Boulad F, Oeffinger KC \& Sklar CA 2009 Disorders of glucose homeostasis in young adults treated with total body irradiation during childhood: a pilot study. Bone Marrow Transplantation 44 339-343.

Chin D, Sklar C, Donahue B, Uli N, Geneiser N, Allen J, Nirenberg A, David R, Kohn B \& Oberfield SE 1997 Thyroid dysfunction as a late effect in survivors of pediatric medulloblastoma/primitive neurectodermal tumors: a comparison of hyperfractionated versus conventional radiotherapy. Cancer 80 798-804.

Chow EJ, Friedman DL, Yasui Y, Whitton JA, Stovall M, Robison LL \& Sklar CA 2008 Timing of menarche among survivors of childhood acute lymphoblastic leukemia: a report from the Childhood Cancer Survivor Study. Pediatric Blood \& Cancer 50 854-858.

Chow EJ, Friedman DL, Stovall M, Yasui Y, Whitton JA, Robison LL \& Sklar CA 2009 Risk of thyroid dysfunction and subsequent thyroid cancer among survivors of acute lymphoblastic leukemia: a report from the childhood cancer survivors study. Pediatric Blood \& Cancer 53 432-437.

Clayton PE \& Shalet SM 1991a Dose dependency of time of onset of radiation-induced growth hormone deficiency. Journal of Pediatrics 118 226-228.

Clayton PE \& Shalet SM $1991 b$ The evolution of spinal growth after irradiation. Clinical Oncology 3 220-222.

Clayton PE, Shalet SM, Price DA \& Jones PH 1989 Ovarian function following chemotherapy for childhood brain tumours. Medical and Pediatric Oncology 17 92-96.

Constine LS, Woolf PD, Cann D, Mick G, McCormick K, Raubertas RF \& Rubin P 1993 Hypothalamic-pituitary dysfunction after radiation for brain tumors. New England Journal of Medicine 328 87-94.
Costin G 1988 Effects of low-dose cranial radiation on growth hormone secretory dynamics and hypothalamicpituitary function. American Journal of Diseases of Children 142 847-852.

Couto-Silva AC, Trivin C, Esperou H, Michon J, Fischer A \& Brauner R 2000 Changes in height, weight and plasma leptin after bone marrow transplantation. Bone Marrow Transplantation 26 1205-1210.

Crofton PM, Ahmed SF, Wade JC, Stephen R, Elmlinger MW, Ranke MB, Kelnar CJ \& Wallace WH 1998 Effects of intensive chemotherapy on bone and collagen turnover and the growth hormone axis in children with acute lymphoblastic leukemia.

Journal of Clinical Endocrinology and Metabolism 83 3121-3129.

Damewood MD \& Grochow LB 1986 Prospects for fertility after chemotherapy or radiation for neoplastic disease. Fertility and Sterility 45 443-459.

d'Annunzio G, Bonetti F, Locatelli F, Pistorio A \& Lorini R 2005 Insulin resistance in children and adolescents after bone marrow transplant for haematological malignancies. Bone Marrow Transplantation 35 209-210.

Darzy KH, Aimaretti G, Wieringa G, Gattamaneni HR, Ghigo E \& Shalet SM 2003 The usefulness of combined growth hormone $(\mathrm{GH})$ releasing hormone and arginine stimulation test in the diagnosis of radiation induced $\mathrm{GH}$ deficiency is dependent on the time interval. Journal of Clinical Endocrinology and Metabolism 88 95-102.

De Boer H, Blok GJ, Van Lingen A, Teule GJ, Lips P \& van der Veen EA 1994 Consequences of childhood onset growth hormone deficiency for adult bone mass. Journal of Bone and Mineral Research 9 1319-1326.

Diller L, Chow EJ, Gurney GJ, Hudson MM, Kadin-Lottick NS, Kawashima TI, Leisenring WM, Meacham LR, Mertens AC, Mulrooney DA et al. 2009 Chronic disase in the Childhood Cancer Survivor Study Cohort: a review of published findings. Journal of Clinical Oncology 27 2339-2355.

Elisei R, Romei C, Vorontsova T, Cosci B, Veremeychik V, Kushinskaya E, Basolo F, Demidchik EP, Miccoli P, Pinchera A et al. 2001 RET/PTC rearrangements in thyroid nodules: studies in irradiated and non irradiated malignant and benign thyroid lesions in children and adults. Journal of Clinical Endocrinology and Metabolism 86 3211-3216.

Ergun-Longmire B, Mertens AC, Mitby P, Qin J, Heller G, Shi W, Yasui Y, Robison LL \& Sklar CA 2006 Growth hormone treatment and risk of second neoplasm in the childhood cancer survivor. Journal of Clinical Endocrinology and Metabolism 91 3494-3498.

Follin C, Thilén U, Ahrén B \& Erfurth EM 2006 Improvement in cardiac systolic function and reduced prevalence of metabolic syndrome after two years of growth hormone $(\mathrm{GH})$ treatment in $\mathrm{GH}$-deficient 
adult survivors of childhood-onset acute lymphoblastic leukemia. Journal of Clinical Endocrinology and Metabolism 91 1872-1875.

Gafni RI \& Baron J 2004 Overdiagnosis of osteoporosis in children due to misinterpretation of dual-energy X-ray absorptiometry (DEXA). Journal of Pediatrics 144 53-57.

Garmey EG, Liu Q, Sklar CA, Meacham LR, Mertens AC, Stovall MA, Yasui Y, Robison LL \& Oeffinger KC 2008 Longitudinal changes in obesity and body mass index among adult survivors of childhood acute lymphoblastic leukemia: a report from the Childhood Cancer Survivor Study. Journal of Clinical Oncology 26 4639-4645.

Gleeson HK, Stoeter R, Ogilvy-Stuart AL, Gattamaneni HR, Brennan BM \& Shalet SM 2003 Improvements in final height over 25 years in growth hormone $(\mathrm{GH})$-deficient childhood survivors of brain tumours receiving $\mathrm{GH}$ replacement. Journal of Clinical Endocrinology and Metabolism 88 3682-3689.

Gleeson HK, Gattamaneni HR, Smethurst C, Brennan BM \& Shalet SM 2004 Reassessment of growth hormone status is required at final height in children treated with growth hormone replacement after radiation therapy. Journal of Clinical Endocrinology and Metabolism 89 662-666.

Green DM, Whitton JA, Stovall M, Mertens AC, Donaldson SS, Ruymann FB, Pendergrass TW \& Robison LL 2002 Pregnancy outcome of female survivors of childhood cancer: a report from the Childhood Cancer Survivor Study. American Journal of Obstetrics and Gynecology 187 1070-1080.

Green DM, Kawashima T, Stovall M, Leisenring W, Sklar CA, Mertens AC, Donaldson SA, Byrne J \& Robison LL 2009 Fertility of female survivors of childhood cancer: a report from the Childhood Cancer Survivor Study. Journal of Clinical Oncology 27 2677-2685.

Greulich W \& Pyle S 1959 Radiographic atlas of skeletal development of the hand and wrist. edn 2. Stanford, CA, USA: Stanford University Press.

Griffin JE \& Wilson JD 1992 Disorders of the testes and the male reproductive tract. In Williams Textbook of Endocrinology, vol 8, pp 799-852. Eds JD Wilson \& DW Foster. Philadelphia: W.B. Saunders.

Grigg AP, McLachlan R, Zajac J \& Szer J 2000 Reproductive status in long-term bone marrow transplant survivors receiving busulfan-cyclophosphamide $(120 \mathrm{mg} / \mathrm{kg})$.

Bone Marrow Transplantation 26 1089-1095.

Growth Hormone Research Society 2000 Consensus guidelines for the diagnosis and treatment of growth hormone $(\mathrm{GH})$ deficiency in childhood and adolescence: summary statement of the GH Research Society. Journal of Clinical Endocrinology and Metabolism 85 3990-3993.

Gurney JG, Kadan-Lottick NS, Packer RJ, Neglia JP, Sklar CA, Punyko JA, Stovall M, Yasui Y, Nicholson HS, Wolden S et al. 2003a Endocrine and cardiovascular late effects among adult survivors of childhood brain tumors: Childhood Cancer Survivor Study. Cancer 97 663-673.

Gurney JG, Ness KK, Stovall M, Wolden S, Punyko JA, Neglia JP, Mertens AC, Packer RJ, Robison LL \& Sklar CA 2003b Final height and body mass index among adult survivors of childhood brain cancer: Childhood Cancer Survivor Study. Journal of Clinical Endocrinology and Metabolism 88 4731-4739.

Halton JM, Atkinson SA, Fraher L, Webber C, Gill GJ, Dawson S \& Barr RD 1996 Altered mineral metabolism and bone mass in children during treatment for acute lymphoblastic leukemia. Journal of Bone and Mineral Research 11 1774-1783.

Hamre MR, Robison LL, Nesbit ME, Sather HN, Meadows AT, Ortega JA, D’Angio GJ \& Hammond GD 1987 Effects of radiation on ovarian function in long term survivors of childhood acute lymphoblastic leukemia: a report from the Children Cancer Study Group. Journal of Clinical Oncology 5 1759-1765.

Heikens J, Behrendt H, Adriaanse R \& Berghout A 1996 Irreversible gonadal damage in male survivors of pediatric Hodgkin's disease. Cancer $\mathbf{7 8}$ 2020-2024.

Himelstein-Braw R, Peters H \& Faber M 1978 Morphological studies of the ovaries of leukaemic children. British Journal of Cancer 38 82-87.

Hoffmeister PA, Storer BE \& Sanders JE 2004 Diabetes mellitus in long-term survivors of peiatric hematopietic cell transplantation. Journal of Pediatric Hematology/Oncology 26 81-90.

Holm K, Nysom K, Rasmussen MH, Hertz H, Jacobsen N, Skakkebaek NE, Krabbe S \& Muller J 1996 Growth, growth hormone and final height after bone marrow transplantation: possible recovery of irradiation-induced growth hormone insufficiency. Bone Marrow Transplantation 18 163-170.

Holm K, Nysom K, Brocks V, Hertz H, Jacobsen N \& Muller J 1999 Ultrasound B-mode changes in the uterus and ovaries and Doppler changes in the uterus after total body irradiation and allogeneic bone marrow transplantation in childhood. Bone Marrow Transplantation 23 259-263.

Horning SJ, Hoppe RT, Kaplan HS \& Rosenberg SA 1981 Female reproductive potential after treatment for Hodgkin's disease. New England Journal of Medicine 304 1377-1382.

Hows JM, Passweg JR, Tichelli A, Locasciulli A, Szydlo R, Bacigalupo A, Jacobson N, Ljungman P, Cornish J, Nunn A et al. 2006 Comparison of long-term outcomes after allogeneic hematopoietic stem cell transplantation from matched sibling and unrelated donors. Bone Marrow Transplantation 38 799-805.

Hudson MM, Greenwald C, Thompson E, Wilimas J, Marina N, Fairclough D, Kauffman W, Bozeman P, Mackert PW, Abromowitch M et al. 1993 Efficacy and toxicity of 
multiagent chemotherapy and low-dose involved field radiotherapy in children and adolescents with Hodgkin's disease. Journal of Clinical Oncology 11 100-108.

Izard MA 1995 Leydig cell function and radiation: a review of the literature. Radiotherapy and Oncology 34 1-8.

Jones TS, Kaste SC, Liu W, Cheng C, Yang W, Tantisira KG, Pui CH \& Relling MV 2008 CRHR1 polymorphisms predict bone density in survivors of acute lymphoblastic leukemia. Journal of Clinical Oncology 26 3031-3037.

Kenney LB, Laufer MR, Grant FD, Grier H \& Diller L 2001 High risk of infertility and long term gonadal damage in males treated with high dose cyclophosphamide for sarcoma during childhood. Cancer 91 613-621.

Lam KSL, Tse VKC, Wang C, Yeung RT \& Ho JH 1991 Effects of irradiation on hypothalamic-pituitary function: a 5-year longitudinal study in patients with nasopharyngeal carcinoma. Quarterly Journal of Medicine 78 165-176.

Larsen E, Muller J, Schmiegelow K, Rechnitzer C \& Andersen AN 2003 Reduced ovarian function in long-term survivors of radiation and chemotherapytreated childhood cancer. Journal of Clinical Endocrinology and Metabolism 88 5307-5314.

Larsen EC, Schmiegelow K, Rechnitzer C, Loft A, Muller J \& Andersen AN 2004 Radiotherapy at a young age reduces uterine volume of childhood cancer survivors. Acta Obstetricia et Gynecologica Scandinavica 83 96-102.

Laughton SJ, Merchant TE, Sklar CA, Kun LE, Fouladi M, Broniscer A, Morris EB, Sanders RP, Krasin MJ, Shelso J et al. 2008 Endocrine outcomes for children with embryonal brain tumors after risk adapted craniospinal and conformal primary-site irradiation and high-dose chemotherapy with stem cell rescue on the SJMB-96 trial. Journal of Clinical Oncology 26 1112-1118.

Laverdiére C, Cheung N-KV, Kushner BH, Kramer K, Modak S, La Quaglia MP, Wolden S, Ness KK, Gurney JG \& Sklar CA 2005 Long-term complications in survivors of advanced stage neuroblastoma. Pediatric Blood \& Cancer 45 324-332.

Leiper AD, Grant DB \& Chessels JM 1986 Gonadal function after testicular radiation for acute lymphoblastic leukemia. Archives of Disease in Childhood 61 53-56.

Lewis K \& Lee PA 2009 Endocrinology of male puberty. Current Opinion in Endocrinology, Diabetes and Obesity 16 5-9.

Link K, Moëll C, Garwicz S, Cavallin-Ståhl E, Björk J, Thilén U, Ahrén B \& Erfurth EM 2004 Growth hormone deficiency predicts cardiovascular risk in young adults treated for acute lymphoblastic leukemia in childhood. Journal of Clinical Endocrinology and Metabolism 89 5003-5012.

Lissett CA, Saleem S, Rahim A, Brennan BM \& Shalet SM 2001 The impact of irradiation on GH responsiveness to provocative agents is stimulus dependent: results in 161 individuals with radiation damage to the somatotropic axis. Journal of Clinical Endocrinology and Metabolism 86 663-668.
Lorini R, Cortona L, Scaramuzza A, De Stefano P, Locatelli F, Bonetti F \& Severi F 1995 Hyperinsulinemia in children and adolescents after bone marrow transplantation. Bone Marrow Transplantation 15 873-877.

Lustig RH, Post SR, Srivannaboon K, Rose SR, Danish RK, Burghen GA, Xiong X, Wu S \& Merchant TE 2003a Risk factors for the development of obesity in children surviving brain tumors. Journal of Clinical Endocrinology and Metabolism 88 611-616.

Lustig RH, Hinds PS, Ringwald-Smith K, Christensen RK, Kaste SC, Schreiber RE, Rai SN, Lensing SY, Wu S \& Xiong X 2003b Octreotide therapy of pediatric hypothalamic obesity: a doubleblind, placebo-controlled trial. Journal of Clinical Endocrinology and Metabolism 88 2586-2592.

Mackie EJ, Radford M \& Shalet SM 1996 Gonadal function following chemotherapy for childhood Hodgkin's disease. Medical and Pediatric Oncology 27 74-78.

Mariotto AB, Rowland JH, Yabroff KR, Scoppa S, Hachey M, Ries L \& Feuer EJ 2009 Long-term survivors of childhood cancers in the United States. Cancer Epidemiology, Biomarkers \& Prevention 18 1033-1040.

Mason PW, Krawiecki N \& Meacham LR 2002 The use of dextroamphetamine to treat obesity and hyperphagia in children treated for craniopharyngioma. Archives of Pediatrics \& Adolescent Medicine 156 887-892.

Matsumoto M, Shinohara O, Ishiguro H, Shimizu T, Hattori K, Ichikawa M, Yabe H, Kubota C, Yabe M \& Kato S 1999 Ovarian function after bone marrow transplantation performed before menarche. Archives of Disease in Childhood 80 452-454.

Meacham LR, Sklar CA, Li S, Liu Q, Gimpel N, Yasui Y, Whitton JA, Stovall M, Robison LL \& Oeffinger KC 2009 Diabetes mellitus in long-term survivors of childhood cancer. Increased risk associated with radiation therapy: a report from the Childhood Cancer Survivor Study. Archives of Internal Medicine 169 1381-1388.

Meistrich ML, Vassillopoulou-Sellin R \& Lipshultz LI 1997 Gonadal dysfunction. In Cancer: Principles and Practice of Oncology, vol 5, pp 2758-2773. Eds VT DeVita Jr, S Hellman \& SA Rosenberg. Philadelphia: Lippincott-Raven.

Metzger ML, Hudson MM, Somes GW, Shorr RI, Li CS, Krasin MJ, Shelso J, Pui CH \& Howard SC $2006 a$ White race as a risk factor for hypothyroidism after treatment for pediatric Hodgkin's lymphoma. Journal of Clinical Oncology 24 1516-1521.

Metzger ML, Howard SC, Hudson MM, Gow KW, Li CS, Krasin MJ, Merchant T, Kun L, Shelso J, Pui CH et al. $2006 b$ Natural history of thyroid nodules in survivors of pediatric Hodgkin lymphoma. Pediatric Blood \& Cancer 46 314-319.

Michel G, Socie G, Gebhard F, Bernaudin F, Thuret I, Vannier JP, Demeocq F, Leverger G, Pico JL, Rubie H et al. 1997 Late effects of allogeneic bone marrow transplantation for children with acute myeloblastic 
leukemia in first complete remission: the impact of conditioning regimen without total-body irradiation - a report from the Société Française de Greffe de Moelle. Journal of Clinical Oncology 15 2238-2246.

Mukherjee A, Tolhurst-Cleaver S, Ryder WD, Smethurst L \& Shalet SM 2005 The characteristics of quality of life impairment in adult growth hormone $(\mathrm{GH})$-deficient survivors of cancer and their response to $\mathrm{GH}$ replacement therapy. Journal of Clinical Endocrinology and Metabolism 90 1542-1549.

Murray RD, Darzy KH, Gleeson HK \& Shalet SM 2002 GH deficient survivors of childhood cancer: $\mathrm{GH}$ replacement during adult life. Journal of Clinical Endocrinology and Metabolism 87 129-135.

Nasir J, Walton C, Lindow SW \& Masson EA 1997 Spontaneous recovery of chemotherapy-induced primary ovarian failure: implication for management. Clinical Endocrinology 46 217-219.

Neville KA, Cohn RJ, Steinbeck KS, Johnston K \& Walker JL 2006 Hyperinsulinemia, impaired glucose tolerance and diabetes mellitus in survivors of childhood cancer: prevalence and risk factors. Journal of Clinical Endocrinology and Metabolism 91 4401-4407.

Nysom K, Holm K, Michaelsen KF, Hertz H, Jacobsen N, Müller J \& Mølgaard C 2000 Bone mass after allogeneic bone marrow transplantation for childhood leukaemia or lymphoma. Bone Marrow Transplantation 25 191-196.

Oberfield SE, Soranno D, Nirenberg A, Heller G, Allen JC, David R, Levine LS \& Sklar CA 1996 Age at the onset of puberty following high-dose central nervous system radiation therapy. Archives of Pediatrics \& Adolescent Medicine 150 589-592.

Oeffinger KC, Mertens AC, Sklar CA, Yasui Y, Fears T, Stovall M, Vik TA, Inskip PD \& Robison LL 2003 Obesity in adult survivors of childhood acute lymphoblastic leukemia: a report from the Childhood Cancer Survivor Study. Journal of Clinical Oncology 21 1359-1365.

Oeffinger KC, Mertens AC, Sklar CA, Kawashima T, Hudson MM, Meadows AT, Friedman DL, Marina N, Hobbie W, Kadan-Lottick NS et al. 2006 Chronic health conditions in adult survivors of childhood cancer. New England Journal of Medicine 355 1572-1582.

Ogilvy-Stuart AL \& Shalet SM 1995 Growth and puberty after growth hormone treatment after irradiation for brain tumours. Archives of Disease in Childhood 73 141-146.

Oglivy-Stuart AL, Wallace WH \& Shalet SM 1994 Radiation and neuroregulatory control of growth hormone secretion. Clinical Endocrinology 41 163-168.

Packer RJ, Boyett JM, Janns AJ, Stavrou T, Kun L, Wisoff J, Russo C, Geyer R, Phillips P, Kieran M et al. 2001 Growth hormone replacement therapy in children with medulloblastoma: use and effect on tumor control. Journal of Clinical Oncology 19 480-487.

Papadakis V, Vlachopapadopoulou E, Van Syckle K, Ganshaw L, Kalmanti M, Tan C \& Sklar C 1999 Gonadal function in young patients successfully treated for Hodgkin's disease. Medical and Pediatric Oncology 32 366-372.

Patterson BC, Truxillo L, Wasilewski-Masker K, Mertens AC \& Meacham LR 2009 Adrenal function testing in pediatric cancer survivors. Pediatric Blood \& Cancer $\mathbf{5 3}$ 1302-1307.

Picco P, Garaventa A, Claudiani F, Gattorno M, De Bernardi B \& Borrone C 1995 Primary hypothyroidism as a consequence of 131-I-metaiodobenzylguanidine treatment for children with neuroblastoma. Cancer $\mathbf{7 6}$ 1662-1664.

Reilly JJ, Vetham JC, Ralston JM, Donaldson M \& Gibson B 1998 Reduced energy expenditure in pre-obese children treated for acute lymphoblastic leukemia. Pediatric Research 44 557-562.

Reilly JJ, Kelly A, Ness P, Dorosty AR, Wallace WH, Gibson BE, Emmett PM \& ALSPAC Study Team 2001 Premature adiposity rebound in children treated for acute lymphoblastic leukaemia. Journal of Clinical Endocrinology and Metabolism 86 3742-3745.

Reiter EO \& Rosenfeld RG 2003 Normal and abnormal growth. In Williams Textbook of Endocrinology, pp 1003-1014. Eds PR Larsen, HM Kronenberg \& S Melmed. Philadelphia: WB Saunders.

Relander T, Gavallin-Stahl E, Garwicz S, Olsson AM \& Willen M 2000 Gonadal and sexual function in men treated for childhood cancer. Medical and Pediatric Oncology 35 52-63.

Rivkees SA \& Crawford JD 1988 The relationship of gonadal activity and chemotherapy-induced gonadal damage. Journal of the American Medical Association 259 2123-2125.

Robison LL, Armstrong GT, Boice JD, Chow EJ, Davies SM, Donaldson SS, Green DM, Hammond S, Meadows AT, Mertens AC et al. 2009 The Childhood Cancer Survivor Study: a National Cancer Institute-supported resource for outcome and intervention research. Journal of Clinical Oncology 27 2308-2318.

Romerius P, Ståhl O, Moëll C, Relander T, Cavallin-Ståhl E, Wiebe T, Giwercman YL \& Giwercman A 2009 Hypogonadism risk in men treated for childhood cancer. Journal of Clinical Endocrinology and Metabolism 94 4180-4186.

Rose SR, Lustig RH, Pitukcheewanont P, Broome DC, Burghen GA, Li H, Hudson MM, Kun LE \& Heideman RL 1999 Diagnosis of hidden central hypothyroidism in survivors of childhood cancer. Journal of Clinical Endocrinology and Metabolism 84 4472-4479.

Rose SR, Schreiber RE, Kearney NS, Lustig RH, Danish RK, Burghen GA \& Hudson MM 2004 Hypothalamic dysfunction after chemotherapy. Journal of Pediatric Endocrinology and Metabolism 17 55-66.

Rose SR, Danish RK, Kearney NS, Schreiber RE, Lustig RH, Burghen GA \& Hudson MM 2005 ACTH deficiency in childhood cancer survivors. Pediatric Blood \& Cancer 45 808-813. 
Ross JA, Oeffinger KC, Davies SM, Mertens AC, Langer EK, Kiffmeyer WR, Sklar CA, Stovall M, Yasui Y \& Robison LL 2004 Genetic variation in the leptin receptor gene and obesity in survivors of childhood acute lymphoblastic leukemia: a report from the Childhood Cancer Survivor Study. Journal of Clinical Oncology 22 3558-3562.

Sala A \& Barr RD 2007 Osteopenia and cancer in children and adolescents: the fragility of success. Cancer 109 1420-1431.

Sanders JE 2004 Endocrine complications of high-dose therapy with stem cell transplantation. Pediatric Transplantation 8 39-50.

Sanders JE, Pritchard S, Mahoney P, Amos D, Buckner CD, Witherspoon RP, Deeg HJ, Doney KC, Sullivan KM, Appelbaum FR et al. 1986 Growth and development following marrow transplantation for leukemia. Blood $\mathbf{6 8}$ 1129-1135.

Sanders JE, Buckner CD, Amos D, Levy W, Appelbaum FR, Doney K, Storb R, Sullivan KM, Witherspoon RP \& Thomas ED 1988 Ovarian function following marrow transplantation for aplastic anemia or leukemia. Journal of Clinical Oncology 6 813-818.

Sanders JE, Hawley J, Levy W, Gooley T, Buckner CD, Deeg HJ, Doney K, Storb R, Sullivan K, Witherspoon R et al. 1996 Pregnancies following high-dose cyclophosphamide with or without high-dose busulfan or total-body irradiation and bone marrow transplantation. Blood $\mathbf{8 7}$ 3045-3052.

Sarafoglou K, Boulad F, Gillio A \& Sklar C 1997 Gonadal function after bone marrow transplantation for acute leukemia during childhood. Journal of Pediatrics 130 210-216.

Schmiegelow M, Feldt-Rasmussen U, Rasmussen AK, Poulsen HS \& Muller J 2003 A population-based study of thyroid function after radiotherapy and chemotherapy for a childhood brain tumor. Journal of Clinical Endocrinology and Metabolism 88 136-140.

Shalet SM, Horner A, Ahmed SR \& Morris-Jones PH 1985 Leydig cell damage after testicular irradiation for lymphoblastic leukemia. Medical and Pediatric Oncology 13 65-68.

Shalet SM, Gibson B, Swindell R \& Pearson D 1987 Effects of spinal irradiation on growth. Archives of Disease in Childhood 62 461-464.

Shalet SM, Tsatsoulis A, Whitehead E \& Read G 1989 Vulnerability of the human Leydig cell to radiation damage is dependent upon age. Journal of Endocrinology 120 161-165.

Sigurdson AJ, Ronckers CM, Mertens AC, Stovall M, Smith SA, Liu Y, Berkow RL, Hammond S, Neglia JP, Meadows AT et al. 2005 Primary thyroid cancer after a first tumour in childhood (the Childhood Cancer Survivor Study): a nested case-control study. Lancet 365 2014-2023.

Sigurjonssdottir T \& Hayes A 1968 Precocious puberty: a report of 96 cases. American Journal of Diseases of Children 1115 309-321.
Siimes MA, Rautonen J, Makipernaa A \& Sipila I 1995 Testicular function in adult males surviving childhood malignancy. Pediatric Hematology and Oncology 12 231-241.

Sklar CA 1997 Growth and neuroendocrine dysfunction following therapy for childhood cancer. Pediatric Clinics of North America 44 489-503.

Sklar C 1999 Reproductive physiology and treatment-related loss of sex-hormone production. Medical and Pediatric Oncology 33 2-8.

Sklar CA \& Constine LS 1995 Chronic neuro-endocrinological sequelae of radiation therapy. International Journal of Radiation Oncology, Biology, Physics 31 1113-1120.

Sklar CA, Kim TH \& Ramsay NKC 1984 Testicular function following bone marrow transplantation performed during or after puberty. Cancer 53 1498-1501.

Sklar C, Sarafoglou K \& Whittam E 1993 Efficacy of insulin-like growth factor binding protein-3 (IGFBP-3) in predicting the growth hormone response to provocative testing in children treated with cranial irradiation. Acta Endocrinologica 129 511-515.

Sklar C, Whitton J, Mertens A, Stovall M, Green D, Marina N, Greffe B, Wolden S \& Robison L 2000a Abnormalities of the thyroid in survivors of Hodgkin's disease: data from the Childhood Cancer Survivor Study. Journal of Clinical Endocrinology and Metabolism $\mathbf{8 5}$ 3227-3232.

Sklar CA, Mertens AC, Walter A, Mitchell D, Nesbit ME, O'Leary M, Hutchinson R, Meadows AT \& Robison LL $2000 \mathrm{~b}$ Changes in body mass index and prevalence of overweight in survivors of childhood acute lymphoblastic leukemia: role of cranial irradiation. Medical and Pediatric Oncology 35 91-95.

Sklar C, Boulad F, Small T \& Kernan N 2001 Endocrine complications of pediatric stem cell transplantation. Frontiers in Bioscience 1 G12-G22.

Sklar CA, Mertens AC, Mitby P, Occhiogrosso G, Qin J, Heller G, Yasui Y \& Robison LL 2002 Risk of disease recurrence and second neoplasm in survivors of childhood cancer treated with growth hormone: a report from the Childhood Cancer Survivor Study. Journal of Clinical Endocrinology and Metabolism 87 3136-3141.

Sklar CA, Mertens AC, Mitby P, Whitton J, Stovall M, Kasper C, Mulder J, Green D, Nicholson HS, Yasui Y et al. 2006 Premature menopause in survivors of childhood cancer: a report from the Childhood Cancer Survivor Study. Journal of the National Cancer Institute 98 890-896.

van der Sluis IM, van den Heuvel-Eibrink MM, Hahlen K, Krenning EP \& de Muinck Keizer-Schrama SM 2002 Altered bone mineral density and body composition, and increased fracture risk in childhood acute lymphoblastic leukemia. Journal of Pediatrics 141 204-210.

Stanislavejic S \& Babcock AL 1997 Fractures in children treated with methotrexate for leukemia. Clinical Orthopaedics and Related Research 125 139-144. 
Swerdlow AJ, Reddingius RE, Higgins CD, Spoudeas HA, Phipps K, Qiao Z, Ryder WD, Brada M, Hayward RD, Brook CG et al. 2000 Growth hormone treatment of children with brain tumours and risk of tumour recurrence. Journal of Clinical Endocrinology and Metabolism 85 4444-4449.

Talvensaari KK, Lanning M, Tapanainen P \& Knip M 1996 Long term survivors of childhood cancer survivors have an increased risk of manifesting the metabolic syndrome. Journal of Clinical Endocrinology and Metabolism 81 3051-3055.

Taskinen M, Saarinen Pihkala UM, Hovi L \& Lipsanen-Nyman M 2000 Impaired glucose tolerance and dyslipidaemia as late effects after bone marrow transplantation in childhood. Lancet 356 993-997.

Taylor AJ, Croft AP, Palace AM, Winter DL, Reulen RC, Stiller CA, Stevens MC \& Hawkins MM 2009 Risk of thyroid cancer in survivors of childhood cancer: results from the British Childhood Cancer Survivor Study. International Journal of Cancer 125 2400-2405.

Thibaud E, Ramirez M, Brauner R, Flamant F, Zucker JM, Fekete C \& Rappaport R 1992 Preservation of ovarian function by ovarian transposition performed before pelvic irradiation in childhood. Journal of Pediatrics 12 880-884.

Thibaud E, Rodriguez-Macias K, Trivin C, Esperou H, Michon J \& Brauner R 1998 Ovarian function after bone marrow transplantation during childhood. Bone Marrow Transplantation 21 287-290.
Thomas BC, Stanhope R, Plowman PN \& Leiper AD 1993 Growth following single fraction and fractionated total body irradiation for bone marrow transplantation. European Journal of Pediatrics 152 888-892.

Thomas IH, Donohue JE, Ness KK, Dengel DR, Baker KS \& Gurney JG 2008 Bone mineral density in young adult survivors of acute lymphoblastic leukemia. Cancer 113 3248-3256.

Van Santen HM, Vulsma T, Dijkgraaf MG, Blumer RM, Heinen R, Jaspers MW, Geenen MM, Offringa MO, de Vijlder JJ \& van den Bos C 2003 No damaging effect of chemotherapy in addition to radiotherapy on the thyroid axis in young adult survivors of childhood cancer. Journal of Clinical Endocrinology and Metabolism $\mathbf{8 8}$ 3657-3663.

Wallace WH, Shalet SM, Crowne EC, Morris-Jones PH, Gattamaneni HR \& Price DA 1989a Gonadal dysfunction due to cis-platinum. Medical and Pediatric Oncology 17 409-413.

Wallace WHB, Shalet SM, Crown EC, Morris-Jones PH \& Gattamaneni HR 1989b Ovarian failure following abdominal irradiation in childhood: natural history and prognosis. Clinical Oncology 1 75-79.

Wasilewski-Masker K, Kaste SC, Hudson MM, Esiashvili N, Mattano LA \& Meacham LR 2008 Bone mineral density deficits in survivors of childhood cancer: long-term follow-up guidelines and review of the literature. Pediatrics 121 e705-e713.

Weinzimer SA, Homan SA, Ferry RJ \& Moshang T 1999 Serum IGF-1 and IGFBP-3 concentrations do not accurately predict growth hormone deficiency in children with brain tumors. Clinical Endocrinology 51 339-345. 